\title{
Proposed magnetostratigraphy susceptibility magnetostratotype for the Eifelian-Givetian GSSP (Anti-Atlas, Morocco)
}

\author{
1 Department of Geology, University of Texas at Arlington, Arlington, TX 76019 \\ 2 Department of Geology and Geophysics, Louisiana State University, Baton Rouge, LA 70803 \\ 3 Département de Géologie, Institut Scientifique, B.P. 703 - Rabat-Agdal, Morocco \\ 4 Institut des Sciences de l'Evolution, Université Montpellier II, F-34095 Montpellier Cedex 05, France
}

The magnetosusceptibility event and cyclostratigraphy (MSEC) record for the Eifelian-Givetian Global Boundary Stratotype Section and Point (GSSP) located in the western Sahara of southeastern Morocco is used to establish a sequence of magnetostratigraphic susceptibility units organized into magnetostratigraphic susceptibility zones (MSZ) and magnetostratigraphic susceptibility subzones (MSSZ). Magnetic susceptibility data are summarized into two complete MSZs (Atrous and Mech Irdane) and two partial MSZs (Gheris and Rissani). The Atrous (Upper Eifelian) is comprised of 3 MSSZs and the Mech Irdane (uppermost Eifelian and lowermost Givetian) of 11 MSSZs. The Eifelian-Givetian boundary falls within Mech Irdane MSSZ 2 making the magnetosubzone an important boundary marker unit. Large-scale transgressive and regressive patterns in the MSEC data establish that the Eifelian-Givetian boundary in the GSSP sequence occurs immediately after the first regressive pulse following the transgressive conditions established during the Atrous MSZ. The Lower Kačák/otomari Event occurs in Atrous MSSZ 3 and Kačák/otomari Event occurs in Mech Irdane MSSZ 1. The magnetic properties of the MSZs and MSSZs are tested by comparison with a coeval magnetostratigraphic susceptibility sequence in the Montagne Noire region of southern France.

\section{Introduction}

While the term magnetostratigraphy used alone commonly refers to magnetostratigraphy polarity, the International Subcommission of Stratigraphic Classification clearly intended that magnetostratigraphy susceptibility be given equal consideration in stratigraphic classification (Salvador, 1994:69, 71). The prominence of magnetostratigraphy polarity and polarity related studies is related to many factors such as its relationship to magnetic anomalies and its role as a source of information for positioning landmasses within the plate tectonic system. Shackelton (1999) recently argued that for isotopic (primarily oxygen) and magnetic (excepting polarities) stratigraphic methods to be useful for global correlation purposes, these data sets should be formally tied to GSSPs. We agree and for ten years have been developing the magnetosusceptibility event and cyclostratigraphy (MSEC) method and an MSEC data set that is tied to Devonian stage-boundary GSSPs. It has become clear from this work that high-resolution, high-density data sets are required to adequately identify the MSEC character of the marine sections we have examined. Therefore, our data set now includes more than 50 continuously sampled sections collected at 0.05 to $0.1 \mathrm{~m}$ intervals. In one instance the section is $\sim 270 \mathrm{~m}$ long and includes more than 2,700 samples.

The purpose of this paper is to present the magnetostratigraphic susceptibility record for the Eifelian-Givetian GSSP boundary sequence located at Jbel Mech Irdane in the Anti-Atlas of southeastern Morocco (Figure 1). Magnetostratigraphic susceptibility is based on the existing MSEC signature developed for the GSSP (Crick et al., 1997). Because MSEC data are based on the magnetic properties of rock, in this case the susceptibility of rocks to acquiring an induced magnetization, these data can be used to establish magnetostratigraphic susceptibility units, either magnetostratigraphic susceptibility magnetozones (MSZ) or magnetostratigraphic magnetosubzones (MSSZ), of the type standardized by the International Stratigraphic Guide (Salvador, 1994). We have employed a columnar log as the method of summarizing the complexity of MSEC data into formal MSZs and MSSZs (Figure 2). For the purposes of chronostratigraphy, chronozones and subchronozones based on magnetozones and magnetosubzones respectively are superior to the numbered peaks introduced in Crick et al. (1997) and are a much more objective means of extending the magnetostratigraphic susceptibility away from a magnetostratotype.

\section{Magnetic susceptibility}

Magnetic susceptibility (MS) is a quantitative measure of the amount of iron-bearing minerals in a sample (Nagata, 1961) and as such is a rough proxy for the lithogenic or detrital fraction of marine sediment. It is the stratigraphic variability of this unique magnetic property of rocks that makes MS valuable in stratigraphic classification. It cannot be overstated that MS data are very different from the magnetic polarities that record the magnetic properties of Earth's magnetic field in rocks. Like magnetic polarities that depend on the conservation of iron in rocks, MS also depends on the preservation of iron bearing minerals. However, unlike magnetic polarities that can be easily remagnetized by heating, MS is largely unaffected by low to moderate thermal processes.

Because the low amplitude magnitude of MS varies inversely, by a factor of 2 or 3 , to the carbonate content of marine sediment as it tracks the lithogenic/biogenic ratio (Ellwood and Ledbetter, 1977), MS has also proven useful as a paleoclimatic indicator (Curry et al., 

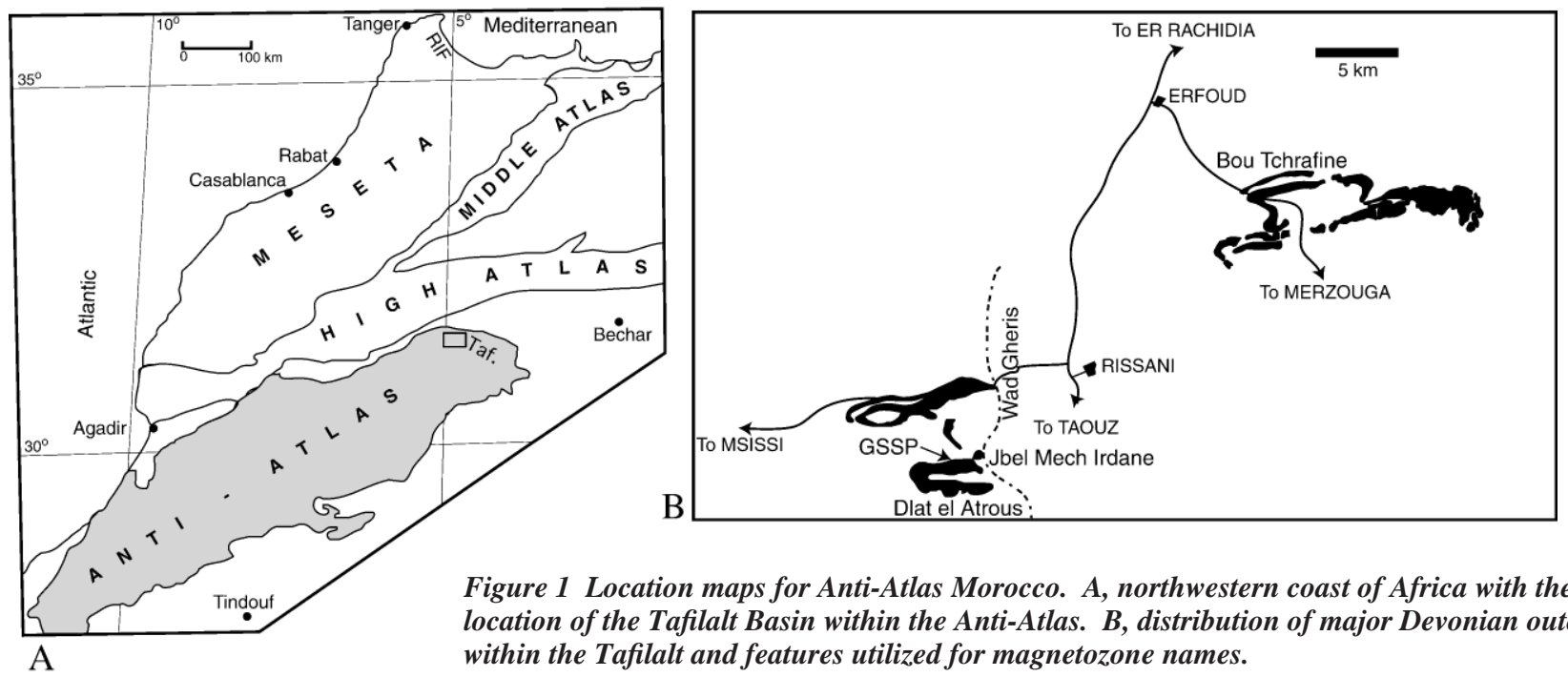

Figure 1 Location maps for Anti-Atlas Morocco. A, northwestern coast of Africa with the location of the Tafilalt Basin within the Anti-Atlas. B, distribution of major Devonian outcrops within the Tafilalt and features utilized for magnetozone names.
1995; Robinson, 1993) and for correlation purposes as a paleoclimate proxy (Shackleton, 1999). The same MS variability is found in shale sequences with little or no carbonate. MS also exhibits large amplitude, long term variations that are independent of carbonate content of samples. These we define as MSZs.

\section{Magnetostratigraphic susceptibility}

Magnetostratigraphy susceptibility is based on variations in the MS record preserved in rocks. Because this character varies stratigraphically, MS is a valuable method of stratigraphic classification. Magnetostratigraphy susceptibility shares two common characteristics of magnetostratigraphy polarity. First, magnetostratigraphic susceptibility units have relatively little individuality (one zone of high-magnitude MS is much the same as another) and, therefore, can usually be identified only by supporting age evidence, such as paleontologic data. Second, like the better known magnetostratigraphic polarity units, magnetostratigraphy susceptibility units are rock units unified by similar magnetic characteristics (exclusive of magnetic polarity) which allow them to be differentiated from adjacent rock bodies (Salvador, 1994). The unifying characteristic of magnetostratigraphy susceptibility units is the iron, usually in the form of magnetite or paramagnetic minerals such as biotite, contained within the lithogenic component of marine sediments that is susceptible to acquiring an induced magnetization in a magnetic field. Most of the MS variations are due to the influx of weathered terrigenous paramagnetic grains although magnetite is usually responsible for a small component of the signal, in some instances as biomagnetite. The basic formal unit in the classification of magnetostratigraphic susceptibility units is the MSZ. MSZs may be subdivided into subzones or MSSZs and, when necessary, grouped into superzones. The definition and recognition of a magnetostratigraphic susceptibility unit should be based on a designated stratotype of the type used in the definition of a GSSP. This criterion provides a definite relationship between a known stratigraphic section with a well-defined biostratigraphic record and a reference section from which magnetostratigraphic susceptibility units can be extended geographically. For this reason we have based the work reported here on the Eifelian-Givetian GSSP (Walliser et al., 1995).

A standard requirement for defining the stratotype of a magnetostratigraphic susceptibility unit is the inclusion of a lower boundary-stratotype and an upper boundary-stratotype. In the likely event of a gradual transition between two susceptibility zones, it is necessary to select an arbitrary boundary within the transition (Salvador, 1994). Because a transition commonly occurs within a lithologic unit, it is helpful to identify magnetostratigraphic susceptibility boundary-stratotypes at the time of establishment by permanent artificial markers. Magnetozones defined in this paper have boundaries picked at mid-points along a transition trend. Following the practice of defining biostratigraphic zones, the base (lower boundary-stratotype) of an MSZ or MSSZ defines the top (upper boundary-stratotype) of the preceding MSZ or MSSZ. Therefore, in the context of this paper, we discuss only the definition of lower boundary-stratotypes.

The naming of magnetostratigraphic susceptibility units follows the general rules for naming stratigraphic units (Salvador, 1994, section 3.B.3). In this context we have designated formal names for MSZs inclusive of bodies of rock with characteristics of either high or low magnitudes of MS that permit the units to be differentiated from adjacent rocks. The formal names for magnetostratigraphic susceptibility units introduced here are taken from local geographic features. Because of the large number of MSSZs, we have opted for a simple system of numbering of these units from oldest to youngest within each MSZ. Use of the MSZ name as a prefix for the MSSZ designation (e.g., Mech Irdane MSSZ 1) allows for unambiguous reference. The adoption of columnar logs as a way of graphically representing MSZs and MSSZs simplifies the correlation and the extension of the correlation of magnetostratigraphic susceptibility units away from a magnetostratotype. We have chosen a diagonally ruled pattern to represent zones of high MS magnitude. White or blank portions of columnar logs represent zones of low MS magnitude. In accordance with established MSEC practice the ruled portions represent intervals of regression or low stands of sea level and white portions represent intervals of transgression or high stands of sea level (Crick et al., 1997; Ellwood et al., 1999).

MSZs share three basic characteristics observed in the Eifelian-Givetian boundary sequence as well as in other boundary and non-boundary sequences. First, MSZs have a dominant magnitude (high or low) but will include lesser-rank units (MSSZs) of the opposite magnitude. Thus MSZs developed during periods of higher than average sea level have a predominantly low-magnitude character and will contain a larger number of low-magnitude magnetosubzones of longer duration than the high-magnitude MSSZs in the MSZ. However, a low-magnitude MSZ may contain low-magnitude MSSZs of shorter duration than some high-magnitude MSSZs. The reverse is the case for magnetozones developed during periods of lower than average sea level. Second, MSZs will begin and end with MSSZs of a magnitude like that which dominants the MSZ. Third, highest- and lowest-magnitude MSSZs occur at or very near the base of MSZs dominated by a similar magnitude.

Appropriate terms for relating magnetostratigraphic susceptibility units to time and space are already available in magnetostratigraphic terminology. The time interval represented by a magnetostratigraphic susceptibility unit is the geochronologic term chron (superchron or subchron as necessary). The chronostratigraphic chronozone is equivalent to a magnetostratigraphic susceptibility unit (superchronozone or subchronozone as necessary) and used to 
refer to all rocks anywhere in the world of the same age as a certain magnetostratigraphic susceptibility zone.

\section{Interpretation of MS patterns}

In general, variations in MS magnitude within a sequence represent changes in the original rate of supply of the iron-bearing lithogenic or detrital fraction to the marine system. Two, somewhat independent controls, constrain the influx of iron-bearing minerals into the marine realm: the degree of climate-induced erosion, and adjustments in base level either through global sea level rise and fall or through tectonically induced changes in altitude of a region relative to sea level. Climate, controlled by orbital forcing cycles, causes variable erosion rates that, in turn, impart a cyclic pattern to sedimentary sequences that is detectable in MS data and useful for cyclostratigraphy as well as magnetostratigraphy susceptibility (Crick et al., 1997; Shackleton, 1999). Cyclic variations in the MS data related to climate form the basis for the unifying characteristics used to define MSSZs. Tectonically induced non-cyclic variations in the MS data form the basis for the unifying characteristics used to define MSZs

\section{The Eifelian-Givetian boundary sequence and proposed magnetostratotype (susceptibility)}

The Eifelian-Givetian GSSP is located at Jbel Mech Irdane in the Tafilalt region of the eastern Anti-Atlas of southern Morocco. The section can be located on the Carte du Maroc 1/50 000, Feuille NH30-XX-2a, Irara. The lithologic and faunal characteristics of the GSSP have been described in detail (Walliser, 1991; Walliser et al., 1995) and the area of Jbel Mech Irdane is thought to have been deposited on the Devonian Tafilalt Platform (Belka et al., 1997). The conodont definition of the Eifelian-Givetian boundary is based on the entry of a definitive form of the conodont species Polygnathus hemiansatus that first appears in bed 123 of the GSSP boundary sequence (Figure 2). Representatives of the ammonoid genus Maenioceras first occur in the upper part of bed 119 in association with representatives of other ammonoid groups known to be common in the Givetian. Thus the base of the Maenioceras Stufe, widely accepted as the base of the Givetian before the GSSP was established, is now some $0.15 \mathrm{~m}$ below the Eifelian-Givetian boundary at the GSSP. The original boundary sequence was composed of 45 beds (Walliser et al., 1995). We extended the original boundary sequence upward into the Givetian by an additional 16 beds (Figure 2 ). The boundary sequence consists mostly of pelagic to hemipelagic limestones (some platy or nodular) with the exception of $0.1 \mathrm{~m}$ of black shale (bed 117) that corresponds to the beginning of the Po. ensensis Zone and the level of the otomari Event (Walliser, 1991; Walliser et al., 1995). House (Walliser et al., 1995) refers the whole of the interval, beds 117 through 119, to the Kačk event. In this and other sections, but certainly not all, this change from limestone to shale facies, marks the disappearance of Tortodus kockelianus kockelianus and the appearance of Po. ensensis.

The MS record for the stratotype at Jbel Mech Irdane is based on 80 samples from 61 beds (Figure 2). The stratigraphic position of samples is shown on the curve of Figure 2. All peaks and trends are composed of multiple data points. The record begins in the T. $k$. kockelianus Zone and continues for $3.9 \mathrm{~m}$ into the Po. varcus Zone (Figure 2). Although the lithology of the sequence is mixed, variations in the magnitude of MS occur independently of lithology. It is this aspect of MS that makes the MSEC record diagnostic of the boundary sequence and predictable among coeval boundary sequences. Details relating to the use of MS in this context are given in Crick et al. (1997). Like the MSEC records of sequences studied and reported thus far, the MSEC record for Jbel Mech Irdane consists of two components of global extent with different temporal aspects: one non-cyclic and one cyclic. It is this characteristic of MSEC that makes possible the distinction between magnetozones (non-cyclic) and magnetosubzones (cyclic).

The Jbel Mech Irdane MSEC record consists of two complete susceptibility magnetozones (Atrous MSZ \& Mech Irdane MSZ) containing 3 and 11 susceptibility magnetosubzones (MSSZ) respectively (Figure 2). It is also possible to describe the late portion of the Gheris MSZ that precedes the Atrous MSZ and the early portion of the Rissani MSZ that succeeds the Mech Irdane MSZ. A complete description of these magnetozones must wait until the boundary sequence can be extended. A summary of the parameters of the magnetostratigraphic susceptibility units discussed in the following sections is given in Table 1.

\section{Gheris Susceptibility Magnetozone}

The Gheris MSZ is a zone of high susceptibility that is already present in bed 101 and ends in bed 109. The lower boundary-stratotype of the succeeding Atrous MSZ, discussed below, defines the top of the Gheris MSZ (Figure 2). The portion of the magnetozone exposed in the boundary sequence occurs near the middle of the T. $k$. kockelianus Zone. We treat the magnetosubzone portion of Gheris MSZ as undifferentiated until the entire magnetozone can be documented. Etymology: Gheris from Wad Gheris, the permanent wadi adjacent to Jbel Mech Irdane and Dlat el Atrous (Figure 1).

\section{Atrous Susceptibility Magnetozone}

The lower boundary-stratotype of the Atrous MSZ is designated at the mid-point of the transition from the high susceptibility of the Gheris MSZ to the low susceptibility of Atrous MSZ (Figure 2). The transition begins in the lower half of bed 108 and ends in lower half of bed 110 with the lower boundary-stratotype fixed in the lowermost portion of bed 109. The Atrous MSZ is a zone of that continues into bed 120. It is equivalent in time and space to the Late Eifelian MSEC Event (Crick et al., 1997; Ellwood et al., 1999). The Lower Kačák/otomari Event of Walliser (Walliser, 1995) occurs in uppermost Atrous MSZ (Upper Atrous MSSZ 3). Atrous MSZ is stratigraphically equivalent to the upper T. k. kockelianus Zone and the lower and middle Po. ensensis Zone. Three magnetosubzones occur within the Atrous MSZ. Etymology: Atrous from Dlat el Atrous, an escarpment located $1 \mathrm{~km}$ south of the GSSP/magnetostratotype (Figure 1).

The Atrous MSZ represents a stratigraphic interval during which MS magnitudes were the lowest for the GSSP sequence. The lower iron content represented by the low MS magnitudes resulted from decreased rates of erosion and delivery associated with a net rise in sea level of unknown proportions (Crick et al., 1997; Ellwood et al., 1999). This relationship between the MSEC record and transgressive/regressive events for the region as it was situated in the Devonian along the northern margin of Gondwana agrees with hypoxic events described for the latest Eifelian (Walliser, 1986; Walliser, 1995). The Atrous MSZ is considered to represent a time during which sea levels were high. Superimposed on the non-cyclic magnetozone record is the cyclic record of 3 magnetosubzones. On the whole, magnetozones describe a pattern with two basic characteristics seen here and in other sequences. First, magnetozones developed during periods of higher than average sea level are dominated by low-magnitude magnetosubzones of longer duration than their high-magnitude counterparts in the same magnetozone. There are some low-magnitude magnetosubzones of shorter duration than the high-magnitude magnetosubzones of the same magnetozone. In this context low-magnitude magnetosubzones account for $92 \%$ of the Atrous MSZ. The reverse is the case for magnetozones developed during periods of lower than average sea level. Second, magnetosubzones defined by either the highest or the lowest MS magnitude occur either at the base of a magnetozone or early in a magnetozone. 
Table 1 Summary of magnetostratigraphic susceptibility unit information relative to the proposed magnetostratotype.

LBS, position within a bed where a specific lower boundary-stratotype is defined; l, lower; m, middle; u, upper; lm, lowermost; um, uppermost; \%MSZ, percent of a particular MSZ occupied by each MSSZ.

\begin{tabular}{|c|c|c|c|c|c|c|}
\hline MSZ & MSSZ & $\begin{array}{r}\text { Ran } \\
\text { GSSI }\end{array}$ & $\begin{array}{l}\text { in } \\
\text { Beds }\end{array}$ & $L B S$ & $\begin{array}{c}\% \\
\mathrm{MSZ}\end{array}$ & Equivalent Conodont Zone \\
\hline Rissani $\boldsymbol{L} \boldsymbol{B S}$ & & 154 & 161 & $\operatorname{lm} 154$ & & 1 Po. varcus \\
\hline \multirow{10}{*}{ Mech Irdane } & 11 & 152 & 154 & um 152 & 9 & 1 Po. varcus \\
\hline & 10 & 150 & 152 & u 150 & 12 & 1 Po. varcus \\
\hline & 9 & 145 & 150 & u 145 & 15 & 1 Po. varcus \\
\hline & 8 & 142 & 145 & 142 & 8 & um Po. hemiansatus, L. Po. varcus \\
\hline & 7 & 139 & 142 & 1139 & 9 & u Po. hemiansatus \\
\hline & 6 & 137 & 139 & 137 & 8 & u Po. hemiansatus \\
\hline & 5 & 135 & 137 & $\mathrm{~m} 135$ & 7 & $\mathrm{~m}$ Po. hemiansatus \\
\hline & 4 & 133 & 135 & m 133 & 6 & $\mathrm{~m}$ Po. hemiansatus \\
\hline & 3 & 130 & 133 & 1130 & 11 & 1 Po. hemiansatus \\
\hline & 2 & 123 & 130 & $\operatorname{lm} 123$ & 8 & Im Po. hemiansatus \\
\hline$L B S$ & 1 & 120 & 123 & um 120 & 7 & u Po. ensensis, $\operatorname{lm}$ Po. hemiansatus \\
\hline \multirow{3}{*}{$\begin{array}{l}\text { Atrous } \\
\boldsymbol{L B S}\end{array}$} & 3 & 112 & 120 & um 111 & 62 & um $T . k$. kockelianus, 1 \& m Po. ensensis \\
\hline & 2 & 110 & 112 & um 110 & 8 & u T. k. kockelianus \\
\hline & 1 & 109 & 110 & $\operatorname{lm} 109$ & 30 & u T. k. kockelianus \\
\hline Gheris & & 101 & 109 & & & m T. k. kockelianus \\
\hline
\end{tabular}

\section{Atrous MSSZ 1}

The initial magnetosubzone for Atrous MSZ (Atrous MSSZ 1) begins in bed 109 and continues into uppermost bed 110. The lower boundary-stratotype of the Atrous MSSZ 1 is the lower boundarystratotype of the magnetozone (Figure 2). The magnetosubzone is composed of one peak of the second lowest magnitude for Atrous MSZ as well as for the GSSP sequence. Atrous MSSZ 1 accounts for $30 \%$ of the magnetozone. Biostratigraphic equivalent: upper T. $k$. kockelianus Zone.

\section{Atrous MSSZ 2}

Atrous MSSZ 2 begins in uppermost bed 110 and ends in lowermost bed 112. The lower boundary-stratotype of Atrous MSSZ 2 is designated at the mid-point of the transition from low susceptibility of bed 110 to higher susceptibility of bed 111 (Figure 2). This is the only magnetosubzone of high susceptibility in the magnetozone and is composed of one peak. It comprises only $8 \%$ of the magnetozone. Biostratigraphic equivalent: upper T. k. kockelianus Zone.

\section{Atrous MSSZ 3}

Atrous MSSZ 3 begins in lowermost bed 112 and ends in bed 120. The lower boundary-stratotype for Atrous MSSZ 3 is defined at the mid-point of the transition from the higher susceptibility of bed 111 to the lower susceptibility of bed 112 (Figure 2). The magnetosubzone represents an interval of consistently low MS magnitude for the Atrous MSZ as well as for the GSSP sequence. Atrous MSSZ 3 represents $62 \%$ of the magnetozone. Biostratigraphic equivalent: uppermost T. k. kockelianus Zone (beds 112-116) and Po. ensensis Zone (beds 117-120).

\section{Mech Irdane Susceptibility Magnetozone}

The lower boundary-stratotype of the Mech Irdane MSZ is designated at the mid-point of the transition from the zone of low susceptibility of the preceding Atrous MSZ to the Mech Irdane MSZ (Fig- ure 2). The transition begins in the upper bed 117 and ends in bed 122. The mid-point along the transition and the base of both the Mech Irdane MSZ and Mech Irdane MSSZ 1 is in the upper portion of bed 120. The base of the succeeding Rissani MSZ, discussed later, defines the top of the Mech Irdane MSZ (Figure 2). Mech Irdane MSZ is a zone of high susceptibility that continues into bed 154 . The magnetozone is equivalent to the upper one-third of Po. ensensis Zone, the whole of the Po. hemiansatus Zone, and much of the Lower Po. varcus Zone. Eleven magnetosubzones occur within Mech Irdane MSZ. Etymology: Mech Irdane from Jbel Mech Irdane, the site of the Eifelian-Givetian GSSP (Figure 1).

The Mech Irdane MSZ represents a stratigraphic interval during which MS magnitudes were the highest for the GSSP sequence. The higher magnetic iron content represented by the high MS magnitudes resulted from increased rates of erosion and delivery associated with a net fall in sea level of unknown proportions (Crick et al., 1997; Ellwood et al., 1999). This relationship between the MSEC record and transgressive/regressive conditions for the region during the latest Eifelian and earliest Givetian is in agreement with independent accounts (Bultynck, 1985; Bultynck, 1987; Walliser, 1986; Walliser, 1995; Wendt, 1988). Mech Irdane MSZ is considered to have represented a chron during which sea levels were low. Highmagnitude magnetosubzones account for $58 \%$ of the magnetozone.

\section{Mech Irdane MSSZ 1}

The initial magnetosubzone for Mech Irdane MSZ (Mech Irdane MSSZ 1) begins in bed 120 and continues through bed 122 and into lowermost bed 123 just above the base of the Givetian. The lower boundary-stratotype of the Mech Irdane MSSZ 1 is the same as the magnetozone (Figure 2). Mech Irdane MSSZ 1 is composed of one peak and represents 7\% of the total susceptibility for Mech Irdane MSZ. The Upper Kačák/otomari Event of Walliser (Walliser, 1995) occurs near the top of the magnetosubzone. Biostratigraphic equivalent: upper one-third Po. ensensis Zone and lowermost Po. hemiansatus Zone. 


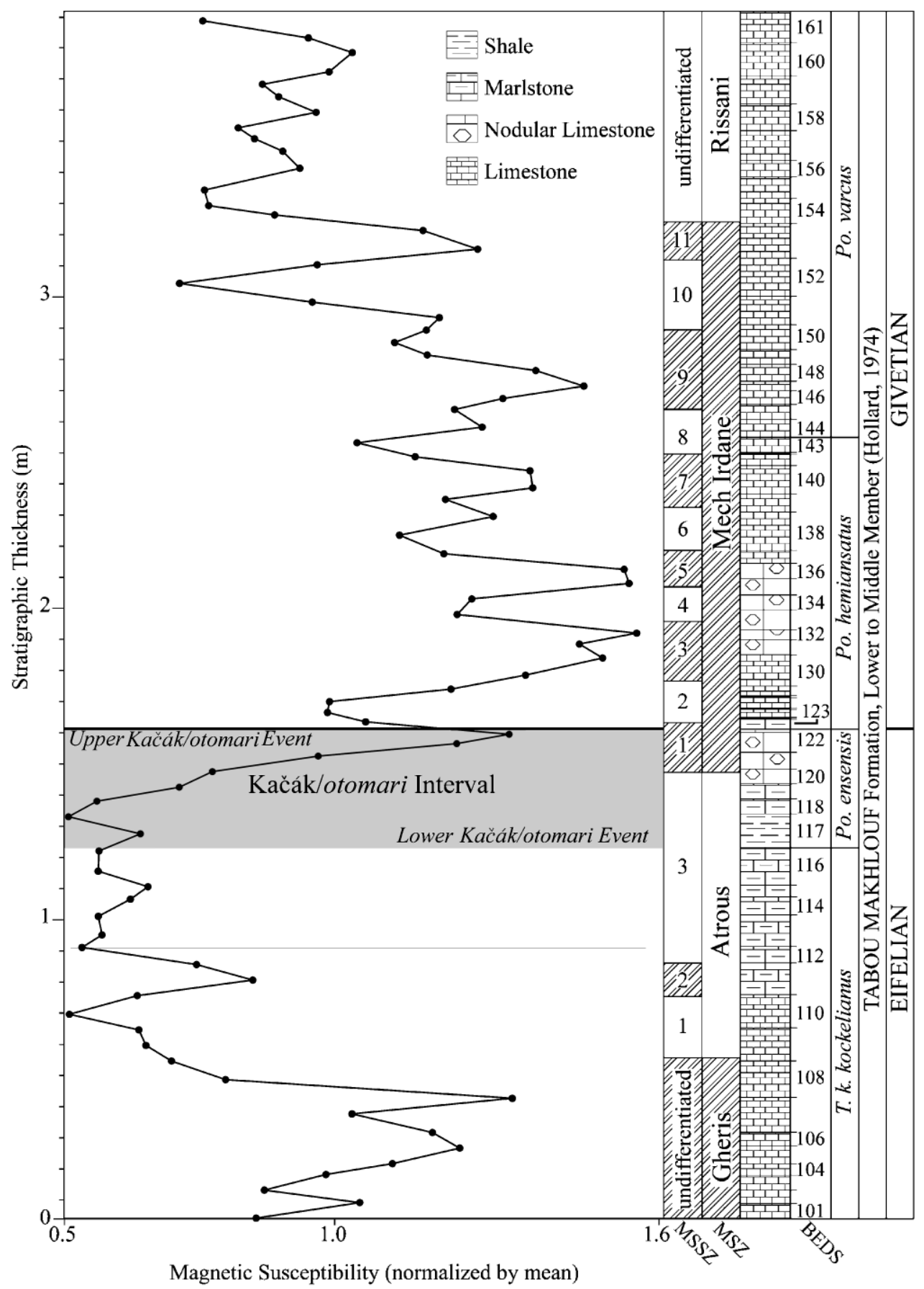

Figure 2 MSEC profile for the Eifelian-Givetian GSSP at Jbel Mech Irdane, Tafilalt, southeastern Morocco. Bed numbers 101-146 and conodont zonation from Walliser et al. (1995). Bed numbers 147-161 from Crick et al (1997). Sample points indicated by black dots on curve. MSZ, magnetozone; MSSZ, magnetosubzone. Intervals of high MS magnitudes indicated by diagonally ruled patterns. Intervals of low MS magnitudes indicated by no pattern. Undifferentiated portions of MSSZ column belong to partial magnetozones. See text for discussion of the Kačák/otomari Event.

\section{Mech Irdane MSSZ 2}

Mech Irdane MSSZ 2 begins in bed 123 and ends in lowermost bed 130 (Figure 2). The lower boundary-stratotype of Mech Irdane MSSZ 2 is designated at the mid-point of the transition from high susceptibility of bed 122 to lower susceptibility of bed 126 . The magnetosubzone is composed of one peak of low susceptibility relative to the magnetozone and represents $8 \%$ of the total susceptibility for Mech Irdane MSZ. Biostratigraphic equivalent: lowermost Po. hemiansatus Zone.

\section{Mech Irdane MSSZ 3}

Mech Irdane MSSZ 3 begins at the base of bed 130 and ends in bed 133. The lower boundary-stratotype of Mech Irdane MSSZ 3 is defined at the mid-point of the transition from the low susceptibility of bed 126 to the higher susceptibility of bed 130 (Figure 2). This magnetosubzone is the interval of the highest susceptibility for the magnetozone and represents $11 \%$ of the total susceptibility for Mech Irdane MSZ, the second longest duration for the magnetozone. Biostratigraphic equivalent: lower Po. hemiansatus Zone. 


\section{Mech Irdane MSSZ 4}

Mech Irdane MSSZ 4 begins in bed 133 and ends in bed 135 (Figure 2). Its lower boundary-stratotype is designated at the midpoint of the transition from high susceptibility of bed 132 to lower susceptibility of bed 134 . The magnetosubzone is composed of one peak of low susceptibility relative to the magnetozone and represents $6 \%$ of the total susceptibility for Mech Irdane MSZ. Biostratigraphic equivalent: middle Po. hemiansatus Zone.

\section{Mech Irdane MSSZ 5}

Mech Irdane MSSZ 5 begins in bed 135 and ends in bed 137. The lower boundary-stratotype of Mech Irdane MSSZ 5 is designated at the mid-point of the transition from the low susceptibility of bed 134 to the higher susceptibility of bed 135 (Figure 2). The magnetosubzone is an interval of high susceptibility and represents $7 \%$ of the total susceptibility for Mech Irdane MSZ. Biostratigraphic equivalent: middle Po. hemiansatus Zone.

\section{Mech Irdane MSSZ 6}

Mech Irdane MSSZ 6 begins in bed 137 and ends in bed 139 (Figure 2). The lower boundary-stratotype of the magnetosubzone is designated at the mid-point of the transition from high susceptibility of bed 136 to lower susceptibility of bed 138 . The magnetosubzone is an interval of low susceptibility relative to the magnetozone and represents $8 \%$ of the total susceptibility for Mech Irdane MSZ. Biostratigraphic equivalent: upper Po. hemiansatus Zone.

\section{Mech Irdane MSSZ 7}

Mech Irdane MSSZ 7 begins in bed 139 and ends in bed 142 . The lower boundary-stratotype of Mech Irdane MSSZ 7 is designated at the mid-point of the transition from the low susceptibility of bed 138 to the higher susceptibility of bed 140 (Figure 2). The magnetosubzone is an interval of high susceptibility and represents $9 \%$ of the total susceptibility for the magnetozone. Biostratigraphic equivalent: upper Po. hemiansatus Zone.

\section{Mech Irdane MSSZ 8}

Mech Irdane MSSZ 8 begins in bed 142 and ends in bed 145 (Figure 2). The lower boundary-stratotype of the magnetosubzone is designated at the mid-point of the transition from high susceptibility of bed 140 to lower susceptibility of bed 143. Mech Irdane MSSZ 8 is an interval of low susceptibility relative to the magnetozone and represents $8 \%$ of the total susceptibility for the magnetozone. Biostratigraphic equivalent: uppermost Po. hemiansatus Zone and earliest Lower Po. varcus Zone.

\section{Mech Irdane MSSZ 9}

Mech Irdane MSSZ 9 begins in bed 145 and ends in bed 150 . The lower boundary-stratotype of Mech Irdane MSSZ 9 is designated at the mid-point of the transition from the low susceptibility of bed 143 to the higher susceptibility of bed 147 (Figure 2). The magnetosubzone is an interval of high susceptibility with a pronounced peak and is the thickest magnetosubzone in the magnetozone representing $15 \%$ of the total susceptibility. Biostratigraphic equivalent: Lower Po. varcus Zone.

\section{Mech Irdane MSSZ 10}

Mech Irdane MSSZ 10 begins in the middle of bed 150 and ends in uppermost bed 152 (Figure 2). The lower boundary-stratotype is designated at the mid-point of the transition from the high susceptibility of bed 147 to lower susceptibility of bed 152 . The magnetosubzone is an interval of low susceptibility with a pronounced peak and $12 \%$ of the total susceptibility for the magnetozone. Biostratigraphic equivalent: Lower Po. varcus Zone.

\section{Mech Irdane MSSZ 11}

Mech Irdane MSSZ 11 begins in the uppermost portion of bed 152 and ends in lowermost bed 154. The lower boundary-stratotype of Mech Irdane MSSZ 11 is at the mid-point of the transition from the low susceptibility of bed 152 to the higher susceptibility of bed 153 (Figure 2). The magnetosubzone is an interval of high susceptibility with a pronounced peak and $9 \%$ of the total susceptibility for the magnetozone. Biostratigraphic equivalent: Lower Po. varcus Zone.

\section{Rissani Susceptibility Magnetozone}

The Rissani MSZ is an interval of low susceptibility that begins with the lower boundary-stratotype near the base of bed 154, continues through bed 161, and ends at some point above the GSSP boundary sequence. The lower boundary-stratotype of the Rissani MSZ is defined by the mid-point of the transition from the zone of high susceptibility of the preceding Mech Irdane MSZ to Rissani MSZ (Figure 2). The transition begins in bed 153 and ends in bed 155. The biostratigraphic equivalent of the exposed portion of the magnetozone in the boundary sequence is a late portion of the Lower Po. varcus Zone. We treat the magnetosubzone portion of Rissani MSZ as undifferentiated until the entire magnetozone can be documented. Etymology: Rissani from the oasis and village of the same name located $10 \mathrm{~km}$ east of the Eifelian-Givetian GSSP (Figure 1).

\section{Correlation away from the proposed magnetostratotype}

Figure 3 illustrates the correlation between the proposed magnetostratotype, a boundary sequence at Bou Tchrafine in the Tafilalt, and a boundary sequence located in the Montagne Noire region of southern France.

\section{Tafilalt, south-eastern Morocco}

The proposed magnetostratotype (Figure $3 \mathrm{~A}$ ) is compared with the boundary sequence at Bou Tchrafine (Figure 3B). Bou Tchrafine is known for its complete but condensed succession of Upper Silurian to Upper Famennian strata and is located approximately $20 \mathrm{~km}$ northeast of Jbel Mech Irdane (Figure 1). The section can be located on the Arfoud 1:50,000 Carte du Maroc, Feuille NH-30-XX-2a. Bou Tchrafine was a candidate for the Eifelian-Givetian GSSP and its lithologic and faunal characteristics are very well documented (Becker and House, 1994; Bultynck, 1985; Bultynck, 1987; Bultynck, 1989; Bultynck and Hollard, 1980; House and Chlupác, 1987; Walliser, 1991). The MSEC signature for Eifelian-Givetian boundary sequence at Bou Tchrafine was reported by Crick et al. (1997) and the MSEC for the Middle and early Upper Devonian has been reported by Ellwood et al. (1999).

The Bou Tchrafine sequence (Figure 3B) is lithologically different from the GSSP but the magnetostratigraphy susceptibility is identical to that of the proposed magnetostratotype. Differences in thickness of MSZs and MSSZs are related to differences in rates of sediment accumulation. The base of the Po. ensensis Zone (dashed line in Atrous MSSZ 3) occurs slightly lower in Bou Tchrafine than the magnetostratotype. The base of Po. hemiansatus Zone at Bou Tchrafine occurs in uppermost Mech Irdane MSSZ 2 as it does in the magnetostratotype. The base of Po. varcus Zone (dashed line in Mech Irdane MSSZ 8) reportedly lies slightly higher in Bou Tchrafine near the base of bed 18 (Bultynck, 1987). Because the base of the Po. hemiansatus Zone occurs in Mech Irdane MSSZ 8 at the Marbrière Nord quarry (Figure 3C), we consider that this discrepancy is due to differences between conodont and MS sampling densities. 


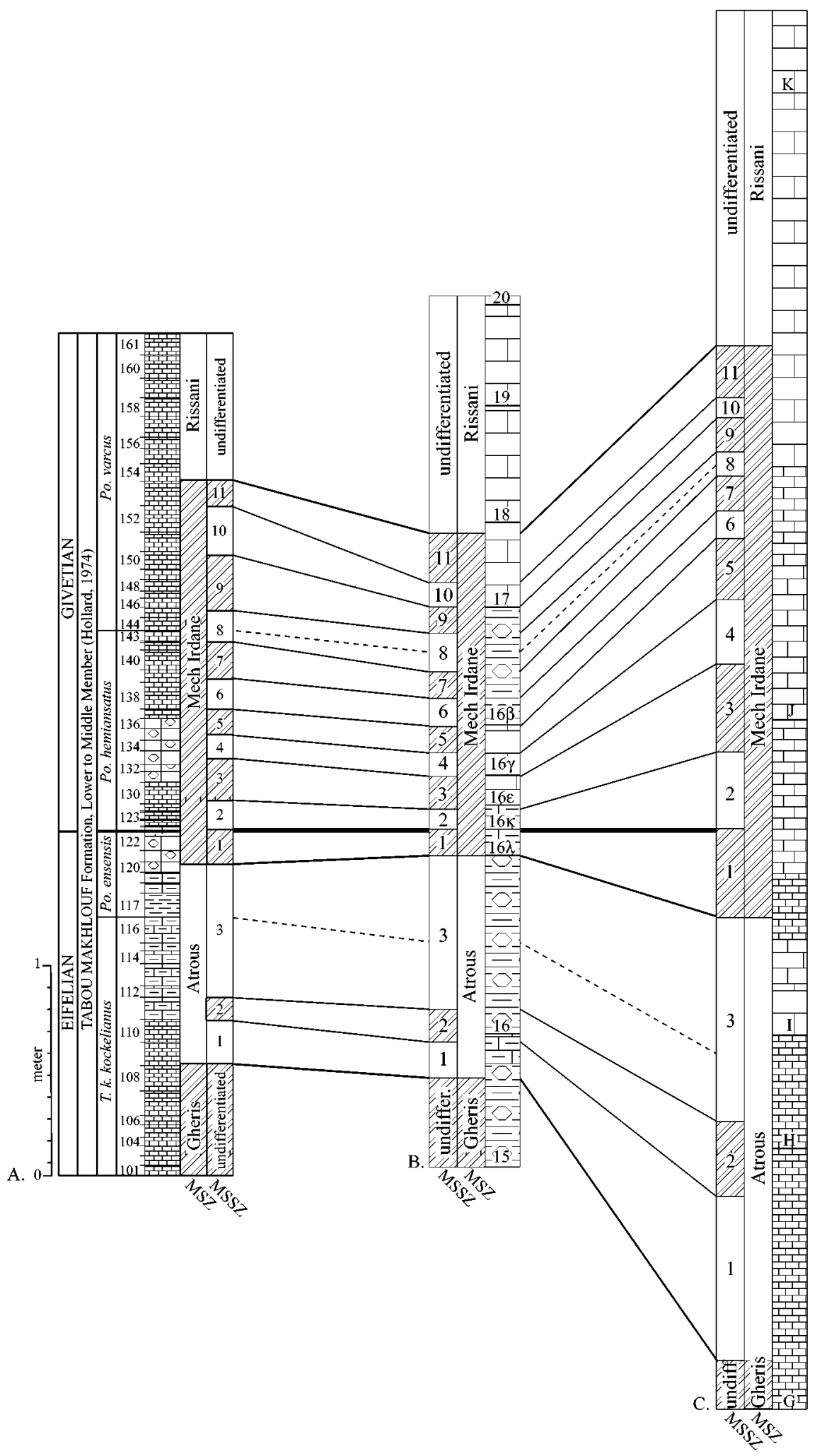

Figure 3 Correlation by magnetostratigraphy susceptibility. Regional and extra-regional correlation of Eifelian-Givetian boundary sequences between the proposed magnetostratotype (A), a second Tafilalt boundary sequence located at Bou Tchrafine (B), and the boundary sequence in the Marbrière Nord quarry $(C)$ within the Pic de Bissous, Montagne Noire, southern France. All sections at the same scale. Patterns and abbreviations are those of Figure 2. Bed numbers for Bou Tchrafine (B) from Becker and House (1994) and conodont zonation from Bultnyck (1987). Bed designations for Marbrière Nord quarry (C) from Feist (1990) and conodont zonation after Walliser (1990). Heavy solid lines connect lower and upper boundary-stratotypes of each magnetozone. Light solid lines between boundary sequences connect lower and upper boundary-stratotypes of magnetosubzones. Dashed lines between boundary sequences connect lower and upper conodont biozone boundaries. 


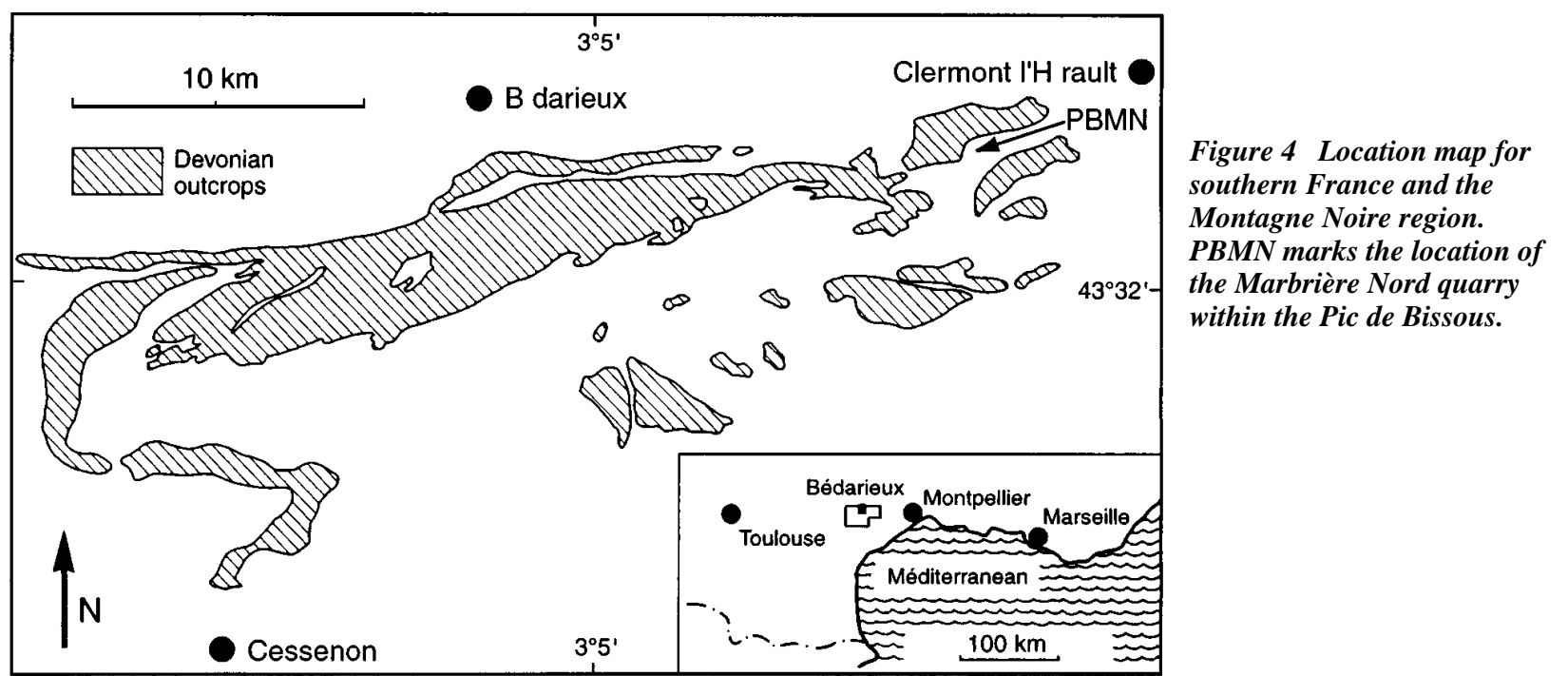

\section{Montagne Noire, southern France}

The well known Eifelian-Givetian boundary sequence of the Marbrière Nord quarry on the northern slope of Pic de Bissous in the southeastern Montagne Noire, Languedoc Province (Figure 4), was chosen for extra-regional comparison (Figure 3C). The Marbrière Nord quarry is located on the 1:25,000 Lodève sheet, 2643 ouest. Detailed descriptions of the sequence can be found in Feist (1985) and Walliser (1990). Crick et al. (1997) have presented and discussed the initial MSEC results for this sequence.

The boundary sequence at Marbrière Nord consists of beds of a pelagic to hemipelagic origin deposited in a basinal environment during the period when the region was part of the northern margin of Gondwana (Galle et al., 1995). The rate of sediment accumulation for this portion of the Marbrière Nord section was approximately $60 \%$ higher than the proposed magnetostratotype.

With exceptions related to the differences in rates of sediment accumulation, the Marbrière Nord magnetostratigraphy susceptibility is the same as that at Jbel Mech Irdane. All of the proposed magnetostratotype zones and subzones are present and provide exact correlation between southern France and southeastern Morocco. The base of the Po. ensensis Zone occurs within Atrous MSSZ 3, the base of the Po. hemiansatus Zone occurs in uppermost Mech Irdane MSSZ 2, and the base of Po. varcus Zone occurs within Mech Irdane MSSZ 8.

\section{Conclusions}

Magnetostratigraphic susceptibility units, especially MSSZs, provide higher resolution for the correlation of marine strata than coeval biozones. However, the magnetostratigraphic susceptibility units remain complimentary to the biostratigraphy because they rely on the biostratigraphic zonation for temporal control.

The proposed Eifelian-Givetian magnetostratotype is based on the conversion of the MSEC record of the Eifelian-Givetian GSSP into two complete MSZs (Atrous and Mech Irdane) and two partial MSZs (Gheris and Rissani), each containing several MSSZs. The number of MSSZs significantly increases the resolution of correlation over that of the standard conodont zonation for the boundary sequence. The extension of the magnetostratigraphic susceptibility units from the proposed magnetostratotype to another area of the Tafilalt (Bou Tchrafine) and to the Montagne Noire region of southern France demonstrates their fidelity in regional and extra-regional of correlation. Within the proposed magnetostratotype, Mech Irdane MSSZ 2 contains the Eifelian-Givetian boundary and is valuable as a marker unit among the boundary sequences investigated.
Large-scale transgressive and regressive patterns in the MSEC data establish that the Eifelian-Givetian boundary in the GSSP sequence occurs immediately after the first regressive pulse following the transgressive conditions established during the Atrous MSZ. The Lower Kačák/otomari Event occurs in Atrous MSSZ 3 and the UpperKačák/otomari Event occurs in Mech Irdane MSSZ 1.

\section{Acknowledgements}

The research was made possible by grants from the Petroleum Research Fund of the American Chemical Society (\#30845-AC8 \& \#34259-AC8) to Crick and Ellwood. We gratefully acknowledge the considerable logistical support provided by the Institut Scientifique, Université Mohammed V, Rabat, Morocco.

\section{References}

Becker, R.T., and House, M.R., 1994, International Devonian goniatite zonation, Emsian to Givetian, with new records from Morocco: Courier Forschunginstitut Senckenberg, v. 75, p. 79-135.

Belka, Z., Kaufmann, B., and Bultynck, P., 1997, Conodont-based quantitative biostratigraphy for the Eifelian of the eastern Anti-Atlas, Morocco: Geological Society of America Bulletin, v. 109, p. 643-651.

Bultynck, P., 1985, Lower Devonian (Emsian)-Middle Devonian (Eifelian and lowermost Givetian) conodont successions from the Ma'der and the Tafilalt, southern Morocco: Courier Forschunginstitut Senckenberg, v. 75 , p. 261-286.

Bultynck, P., 1987, Pelagic and neritic conodont successions from the Givetian of pre-Sahara Morocco and the Ardennes: Bulletin de l'Institut Royal des Sciences Naturelles de Belgique. Sciences de la Terre, v. 57, p. 149181.

Bultynck, P., 1989, Conodonts from a potential Eifelian/Givetian Global Boundary Stratotype at Jbel Ou Driss, southern Ma'der, Morocco: Bulletin de l'Institut Royal des sciences naturelles de Belgique, Sciences del la Terre, v. 58, p. 95-103.

Bultynck, P., and Hollard, H., 1980, Distribution comparé de Conodontes et Goniatites dévoniennes des plaines du Dra, du Ma'der et du Tafilalt (Maroc): Aardkundige Mededelingen, v. 1, p. 7-75.

Crick, R.E., Ellwood, B.B., Hassani, A.E., Feist, R., and Hladil, J., 1997 MagnetoSusceptibility Event and Cyclostratigraphy (MSEC) of the Eifelian-Givetian GSSP and associated boundary sequences in north Africa and Europe: Episodes, v. 20, p. 167-175.

Curry, W.B., Schneider, D.A., and Party, L.S., 1995, Ceara Rise sediments document ancient climate change: Eos, v. 76, p. 40-45.

Ellwood, B.B., Crick, R.E., and El Hassani, A., 1999, The MagnetoSusceptibility Event and Cyclostratigraphy (MSEC) method used in geological correlation of Devonian rocks from Anti-Atlas Morocco: American Assoication of Petroleum Geologists Bulletin, v. 83, p. 1119-1134. 
Ellwood, B.B., and Ledbetter, M., 1977, Antarctic bottom water fluctuations in the Vema Channel: effects of velocity changes on particle alignment and size: Earth Planetary Science Letters, v. 35, p. 189-198.

Feist, R., 1985, Devonian stratigraphy of the south-eastern Montagne Noire (France), in Ziegler, W.W., R., (ed), Devonian Series Boundaries Results of world-wide studies.., Volume 75: Frankfurt, Courier Forschunginstitut Senckenberg, p. 331-352.

Feist, R., Becker, R.T., House, M.R., Babin, C., Flaja, G., Klapper, G., Lethiers, F., Pedder, A., Racheboeuf, P., and Truyols-Massoni, M., 1990, The Frasnian - Famennian Boundary and Adjacent Strata of the Eastern Montagne Noire, France.: Montpellier, International Subcommission on Devonian Stratigraphy, $69 \mathrm{p}$.

Galle, A., Hladil, J., and Isaacson, P.E., 1995, Middle Devonian biogeography of closing South Laurussia-North Gondwana Variscides: Examples from the Bohemian Massif (Czech Republic), with emphasis on Horní Benesov: Palaios, v. 10, p. 221-239.

House, M.R., and Chlupác, I., 1987, Goniatite faunas relevant to the definition of the Eifelian/Givetian boundary: Document submitted to the Subcommission on Devonian Stratigraphy, Calgary, August 1987.

Nagata, T., 1961, Rock Magnetism: Tokyo, Maruzen Company Ltd., 350 p.

Robinson, S.G., 1993, Lithostratigraphic applications for magnetic susceptibility logging of deep-sea sediment cores; examples from ODP Leg 115 , in Hailwood, E.A., and Kidd, R.B., ed., High Resolution Stratigraphy, Volume 70: Geological Society Special Publications: London, The Geological Society, p. 65-98.

Salvador, A., 1994, The International Stratigraphic Guide: A Guide to Stratigraphic Classification, Terminology, and Procedure, Boulder, $214 \mathrm{p}$.

Shackleton, N.J., 1999, Will Oxygen isotope stratigraphy survive to the next Millenium: EOS Transactions AGU, Abstracts of Annual Meeting (San Francisco), v. 80, p. F505.

Walliser, O.H., 1986, Global Bio-Events: A Critical Approach, in Bhattacharji, S., Friedman, G.M., Neugebauer, H.J., and Seilacher, A., ed., Lecture Notes in Earth Sciences, Volume 8: Berlin, Springer-Verlag, 442 p.

Walliser, O.H., 1990, Marble Quarry at Pic de Bissous. Remarks on the stratigraphy: Document submitted to the Subcommission on Devonian Stratigraphy, Frankfurt/Main, September 1990, 79 p.

Walliser, O.H., 1991, Morocco Field Meeting of the Subcommission on Devonian Stratigraphy, International Union of Geological Sciences, November 28-December 5, 1991: Guide Book, Göttingen.

Walliser, O.H., 1995, Global events in the Devonian and Carboniferous, in Walliser, O.H., ed., Global Events and Event Stratigraphy in the Phanerozoic: Berlin, Springer-Verlag, p. 225-250.

Walliser, O.H., Bultynck, P., Weddige, K., Becker, R.T., and House, M.R., 1995, Definition of the Eifelian-Givetian Stage boundary: Episodes, v. 18 , p. $107-115$

Wendt, J., 1988, Facies pattern and paleogeography of the Middle and Late Devonian in eastern Anti-Atlas (Morocco), in McMillan, N.J., Embry, Ashton F., Glass, D. J., (ed), Devonian of the world, Volume Volume I, Regional Syntheses: Calgary, Canadian Society of Petroleum Geologists, p. $467-480$.

Rex E. Crick is Professor of Geology at the University of Texas at Arlington. His researches have concentrated on the evolution and biostratigraphy of Paleozoic nautiloid cephalopods and on mid-Paleozoic international chronocorrelation, mainly using MESC data. In conjunction with Prof. Ellwood, the MSEC work has led to the development and use of magnetostratigraphy susceptibility magnetozones as a means of high-resolution chronocorrelation. He is currently Vice-Chairman and Titular Member of the Subcommission on Devonian Stratigraphy.

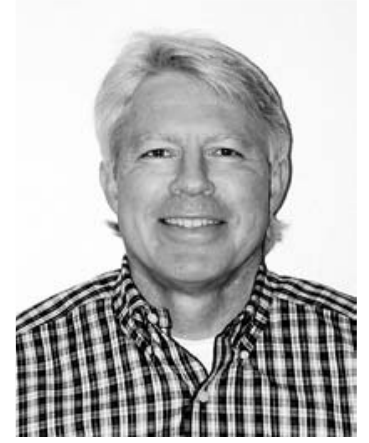

Brooks B. Ellwood is the Chair of the Department of Geology and Geophysics at Louisiana State University in Baton Rouge, Louisiana. His research has concentrated on the magnetic properties of rocks with special emphasis on magnetic susceptibility and its anisotropy. He has applied this research to marine and non-marine materials including volcanic tuffs, granites, coals, deepsea sediments, tar sands, shales, limestones and others. He is also funded to look at long-termpaleoclimates in southern Europe over the last 500,000 years or so.

Ahmed El Hassani is Researcher of Geology at the Institut Scientifique, University of Rabat. His research is concentrated mainly on Paleozoic formations (stratigraphy and structure) in the Moroccan Meseta and the mid-Paleozoic of the Anti-Atlas (southeast Morocco). He also works on Paleozoic correlations between Gondwana and Laurasia. He has collaborated on many Devonian projects in Anti-Atlas Morocco. He is a Corresponding Member of the Subcommission on Devonian Stratigraphy.

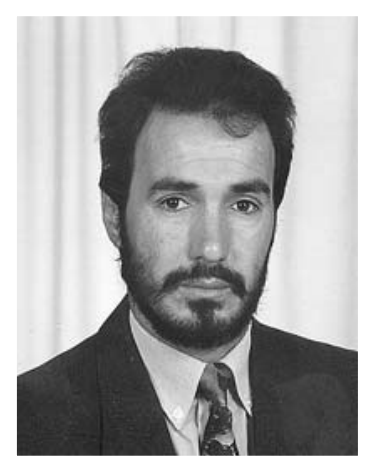

R. Feist is Director of Research with the French National Scientific Research Centre (CNRS) at the University of Montpellier, France. He is co-leader of IGCP Project 421: "North Gondwanan mid-Palaeozoic biodynamics" (1997-2001) and in this frame his research concentrates on trilobite biogeography, evolution and diversity, stratigraphical correlations and biofacies/bio-events. He is a Titular Member of the Subcommission on Devonian Stratigraphy.

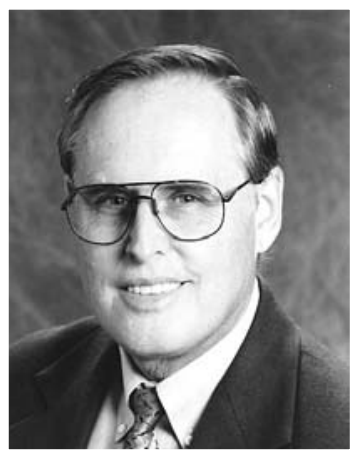

